Research Article

\title{
Neural restrictive silencer factor and choline acetyltransferase expression in cerebral tissue of Alzheimer's Disease patients: A pilot study
}

\author{
Rocío E. González-Castañeda ${ }^{1,2}$, Víctor J. Sánchez-González ${ }^{1}$, Mario Flores-Soto ${ }^{3}$, \\ Gonzalo Vázquez-Camacho, ${ }^{4,2}$, Miguel A. Macías-Islas ${ }^{5}$ and Genaro G. Ortiz ${ }^{1,2}$ \\ ${ }^{1}$ Laboratorio de Desarrollo-Envejecimiento, Enfermedades Neurodegenerativas, División de Neurociencias, \\ Centro de Investigación Biomédica de Occidente, Instituto Mexicano del Seguro Social, Guadalajara, \\ Jalisco, México. \\ ${ }^{2}$ Instituto Tecnológico de Estudios Superiores de Monterrey, División de Ciencias de la Salud, \\ Escuela de Medicina, Campus Guadalajara, Guadalajara, Jalisco, México. \\ ${ }^{3}$ Laboratorio de Investigación y Desarrollo Farmacéutico, \\ Centro Universitario de Ciencias Exactas e Ingenierías, Universidad de Guadalajara, Guadalajara, \\ Jalisco, México. \\ ${ }^{4}$ Departamento de Anatomía Patológica, Unidad Médica de Alta Especialidad, Hospital de Especialidades, \\ Centro Médico Nacional de Occidente, Guadalajara, Jalisco, México. \\ ${ }^{5}$ Departamento de Neurología, Unidad Medica de Alta Especialidad, Hospital de Especialidades, \\ Centro Médico Nacional de OccidenteGuadalajara, Jalisco, México.
}

\begin{abstract}
Decreased Choline Acetyltransferase (ChAT) brain level is one of the main biochemical disorders in Alzheimer's Disease (AD). In rodents, recent data show that the CHAT gene can be regulated by a neural restrictive silencer factor (NRSF). The aim of the present work was to evaluate the gene and protein expression of CHAT and NRSF in frontal, temporal, entorhinal and parietal cortices of $A D$ patient brains. Four brains from patients with $A D$ and four brains from subjects without dementia were studied. Cerebral tissues were obtained and processed by the guanidine isothiocyanate method for RNA extraction. CHAT and NRSF gene and protein expression were determined by reverse transcription-polymerase chain reaction (RT-PCR) and Western blotting. CHAT gene expression levels were $39 \%$ lower in $A D$ patients as compared to the control group ( $p<0.05, \mathrm{U}$ test). ChAT protein levels were reduced by $17 \%$ $(p=0.02$, $U$ test). NRSF gene expression levels were $86 \%$ higher in the AD group $(p=0.001, U$ test $)$ as compared to the control group. In the AD subjects, the NRSF protein levels were $57 \%$ higher ( $p>0.05, U$ test) than in the control subjects. These findings suggest for the first time that in the brain of AD patients high NRSF protein levels are related to low CHAT gene expression levels.
\end{abstract}

Keywords: neural restrictive silencer factor, choline acetyltransferase, Alzheimer's disease, protein expression, brain.

Received: June 7, 2012; Accepted: October 15, 2012.

\section{Introduction}

Alzheimer's disease (AD) is a progressive, neurodegenerative disease and the most common type of adultonset dementia (Cerpa et al., 2008). Although the etiologic and pathogenic events that lead to this disease are still unknown, highly typical neuropathological changes (amyloid plaques, neurofibrillary tangles and an intense glial reactivity) are observed in the patients' brains (Maccioni et al., 2001; Watson et al., 2005; Haroutunian et al., 2008). Choli-

Send correspondence to Genaro Gabriel Ortiz. Laboratorio de Desarrollo-Envejecimiento, Enfermedades Neurodegenerativas, División de Neurociencias, Sierra Mojada 800, 44340 Guadalajara, Jalisco, México. E-mail: genarogabriel@yahoo.com. nergic dysfunction signaling is an early hallmark of AD (Ikonomovik et al., 2011), one of the most important being a reduction in Choline Acetyltransferase (ChAT) enzyme activity in the cholinergic neurons of the temporal and parietal cortices, the hippocampus, the entorhinal cortex, and the amygdala (Mufson et al., 2003; Abel et al., 2008; Geula et al., 2008)

Decreased ChAT activity in the cerebral cortex has been reported to be related to the severity of Alzheimer's Disease. This reduction is thought to originate from loss or declining function of cholinergic neurons known to be affected in AD (Boissiere et al., 1997; Mufson et al., 2003; Kar et al., 2004; Pakaski and Kalman, 2008). The cholinergic deficit contributes significantly to the neuropsychi- 
atric manifestations of the disease (Auld et al., 2002; Kar et al., 2004). Biochemical and in situ hybridization studies have shown a significant region-dependent loss in ChAT activity (from 30 to 90\%) and ChAT mRNA levels (about $50 \%$ ) in the temporal, frontal and parietal cortices of $\mathrm{AD}$ brains (Wilcock et al., 1982; Coyle et al., 1983; DeKosky et al., 1992; Lehericy et al., 1993; Yan and Feng, 2004; Heese and Akatsu, 2006).

Different studies have shown that the synthesis of the cholinergic neuron-essential molecules involved in cholinergic neurotransmission is controlled by DNA-regulatory elements and DNA-binding proteins (De Gois et al., 2000; Hersh and Shimojo., 2003; Oda et al., 2004). Therefore, the organization of the cholinergic gene locus suggests a coordinated regulation at the transcriptional level (Berrard et al., 1995; Berse and Blusztajn, 1995; Mieda et al., 1997; Tanaka et al., 1998). The mechanism of transcriptional regulation controlling the cholinergic gene is still unclear; however, in cholinergic cells at least two kinds of regulatory elements in the CHAT gene have long been recognized as important for specific gene expression (Lonnerberg et al., 1996; Shimojo et al., 1999).

The neuron-restrictive silencer element (NRSE), which comprises $\sim 23$ nucleotides, has been involved in silencing the cholinergic gene locus in non-neural cells (Chong et al., 1995; Shimojo et al., 1999). It was reported that a transcription factor called neuron-restrictive silencer factor (NRSF/REST) is recruited to NRSE sites, repressing neuron-specific genes in neural cells (Belyaev et al., 2004; Schoenherr and Anderson, 1995; Palm et al., 1999; Wood et al., 2003). In addition, in vitro reports using rodent cell lines have demonstrated that the NRSF binds to rat NRSE to repress the R-type of ChAT in non-neuronal cells (Shimojo et al., 1999; Hersh and Shimojo, 2003). The NRSF/REST gene, REST, is located on chromosome 4q12 in humans (OMIM, *600571), whereas the mouse counterpart is located on chromosome 5 C3.3; 5 (MGI 104897).

It has been shown that the human cholinergic gene locus contains a sequence that is homologous to that of rat NRSE in a corresponding gene region (Hahm et al., 1997). It can therefore be suggested that the cholinergic gene expression is repressed in human neuronal cells by similar mechanisms as in rodents. To date, no comparative studies on CHAT and NRSF expression in patients with Alzheimer's disease were reported. So, we decided to analyze the gene and protein expression in different cortices of Alzheimer's disease patients and of non-demented controls.

\section{Material and Methods}

\section{Subjects: Tissue preparation}

Frontal, temporal, entorhinal and parietal cortices (see Figure 1) were obtained from brains of four autopsied patients with Alzheimer's disease (diagnosed using the DSM-IV and NINCDS-ADRDA criteria) and of four sub-

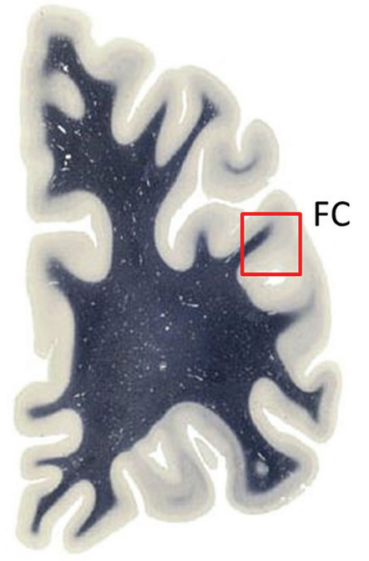

$-30 \mathrm{~mm}$

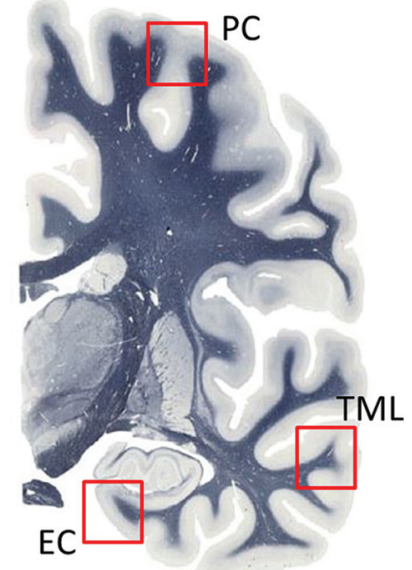

$16 \mathrm{~mm}$
Figure 1 - Human brain sections showing the analyzed areas. Numbers indicate the position of the sections relative to the center of the anterior commissure. FC: frontal cortex; PC: parietal cortex; TML: temporal medial lobe; EC: entorhinal cortex.

jects with no clinical history of or pathological findings suggestive of any neurological or psychiatric diseases. This study was approved by the Ethics Committee of the Instituto Mexicano del Seguro Social (IMSS) and carried out after written consent from the patients' relatives obtained prior to the autopsy. The study was also approved by the CNI-IMSS review board and was carried out according to the principles of the Helsinki declaration, as revised in 2000 (World Medical Association, 2008).

\section{Extraction and quantification of total RNA}

Total RNA was isolated according to the method described by Chomczynski and Sacchi (1987). Briefly, cerebral cortical tissue was homogenized using a polytron system in the presence of Trizol (Invitrogen). Chloroform was added and the RNA was precipitated from the resulting aqueous phase with isopropanol at $4{ }^{\circ} \mathrm{C}$ for $48 \mathrm{~h}$. RNA was resuspended in DEPC-treated water after ethanol precipitation and stored at $-80{ }^{\circ} \mathrm{C}$ until use. RNA samples with a 260/280 $\mathrm{nm}$ absorption ratio between 1.8 and 2.0 were used for further experiments.

\section{Detection of CHAT and NRSF expression by reverse transcription-polymerase chain reaction (RT-PCR)}

Two $\mu \mathrm{g}$ of total RNA were adjusted to a volume of $6 \mu \mathrm{L}$ with DEPC water. Samples were incubated at $70^{\circ} \mathrm{C}$ for $10 \mathrm{~min}$ and cooled quickly on ice. Reverse transcription reactions were performed using $0.1 \mu \mathrm{g}$ of random primer in a $20 \mu \mathrm{L}$ reaction mixture containing $50 \mathrm{mM}$ Tris- $\mathrm{HCl}(\mathrm{pH}$ 8.3), $75 \mathrm{mM} \mathrm{KCl}, 3 \mathrm{mM} \mathrm{MgCl}, 0.2 \mathrm{mM}$ of each deoxynucleotide (Invitrogen), and 4 units of MLV reverse transcriptase (Invitrogen). Reverse transcription was performed at $30{ }^{\circ} \mathrm{C}$ for $10 \mathrm{~min}$ and $37^{\circ} \mathrm{C}$ for $1 \mathrm{~h}$. The reaction was stopped by heating to $99^{\circ} \mathrm{C}$ for $5 \mathrm{~min}$. These mixtures were 
stored at $-80^{\circ} \mathrm{C}$ until use as cDNA templates for the reverse transcription-mediated PCR (RT-PCR). The 5'and 3' primer sequences used for amplification were as follows: CHAT, 5'-TAG CCG ATG ACA GCC TGT GAA TGA CC-'3 (upper primer, base position 61) and 5'-TTG TTG CCA GGA ACA GAG AGT CCA GA-'3 (lower primer, base position 660; GenBank access number: X56585) that amplified a PCR product of $600 \mathrm{bp}$, total cycles: 32 . NRSF, 5'-TGC CGC GAG CTC GCG GCG CAG CAG CG-‘3 (upper primer, base position 1) and 5'-ATA CAG GCT GAG GTT CTA CGA CGC TG-3 (lower primer, base position 720; Genbank access number: NM_005612) that amplified a PCR product of $720 \mathrm{bp}$, total cycles: 36 . G3PDH, 5'-CGC TTC GCT CTC TGC TCC TCC TGT TC-'3 (upper primer, base position 3) and 5'-GGG GTG CTA AGC AGT TGG TGG TGC AG-'3 (lower primer, base position 580; Genbank access number: NM_002046) that amplified a PCR product of $577 \mathrm{bp}$; total cycles: 26 .

The amplification mixture contained cDNA, $50 \mathrm{mM}$ $\mathrm{KCl}, 20 \mathrm{mM}$ Tris- $\mathrm{HCl}$ (pH 8.4), $1.75 \mathrm{mM} \mathrm{MgCl}_{2}, 0.4 \mathrm{mM}$ dNTP, $5 \mu \mathrm{g} / \mathrm{mL}$ of each of the specific upstream and downstream primers, and 0.175 units of Taq DNA polymerase (Invitrogen) in a total reaction volume of $10 \mu \mathrm{L}$. The amplification of DNA fragments of each sample was performed in a thermal cycler (Eppendorf Mastercycler) with an initial denaturation step at $95^{\circ} \mathrm{C}$ for $5 \mathrm{~min}$, followed by various cycles, each consisting of a denaturation step at $95^{\circ} \mathrm{C}$ for 1 min, an annealing step at $60^{\circ} \mathrm{C}$ for $1 \mathrm{~min}$, and a final elongation step at $72{ }^{\circ} \mathrm{C}$ for $1.5 \mathrm{~min}$. PCR products were electrophoresed in a $1.5 \%$ agarose gel containing $0.1 \mu \mathrm{g} / \mathrm{mL}$ ethidium bromide. Gels were photographed under short-wavelength UV. The intensity of the fluorescence level of the product band was determined by densitometry (Alpha Innotech Corporation). The quantities of PCR products of CHAT and NRSF were normalized to the G3PDH level (Figure 5A).

\section{Western blotting for ChAT and NRSF protein}

Brain tissue was ice-homogenized in lysis buffer containing $920 \mu \mathrm{L}$ lysis regulator $(10 \mathrm{mM})$, Tris- $\mathrm{HCl}(\mathrm{pH} 7.5)$, $150 \mathrm{mM}, \mathrm{NaCl}, 20 \mathrm{mM}, \mathrm{NaF}, 0.5 \mathrm{mM}$ sodium orthovanadate, $2 \mathrm{mM}$ sodium pyrophosphate, and $80 \mu \mathrm{L}$ protease inhibitor cocktail (Roche). Samples were incubated on ice for $30 \mathrm{~min}$ and centrifuged at $13,000 \mathrm{rpm}$ at $4{ }^{\circ} \mathrm{C}$. Protein concentration was estimated according to Lowry et al. (1951) using bovine serum albumin (BSA) as standard and $50 \mu \mathrm{g}$ of protein from each sample, before separation on a $12 \%$ SDS-polyacrylamide gel and transfer to nitrocellulose membranes (Sigma). Membranes were blocked with nonfat milk (10\%; Svelty) in phosphate buffer saline (PBS) with $0.25 \%$ Tween-20 for two hours, to avoid non-specific antibody binding. The membranes were then incubated with anti-ChAT (AB144P, Chemicon) and anti-NRSF (P-18, Chemicon) primary antibodies (1:1000) for $24 \mathrm{~h}$. After three washes in PBS with $0.05 \%$ Tween-20 (PBST), the membranes were incubated for $24 \mathrm{~h}$ with donkey anti-goat IgG HRP (1:1000) as the secondary antibody. After three washes with PBST, the membranes were incubated in an ABC Elite Kit (PK 6200; Vector Laboratories) for two hours and, after three washes with PBS of 5 min each, developed with diaminobenzidine (SIGMA). Protein expression was quantitatively determined by densitometry (Figure 5A).

\section{Statistical analyses}

CHAT and NRSF expression differences between groups were analyzed by means of Mann Whitney's U test and the Wilcoxon test. Data are shown as mean \pm standard error of the mean (S.E.M.). Statistical significance was set at $\mathrm{p}<0.05$.

\section{Results}

The brains of four patients with sporadic, severe AD and four control subjects were studied (mean age $64 \pm 8 v s$. $54 \pm 4$ yrs, $p>0.05$ ). None of the patients had been in a coma or shown any other CNS lesions (i.e., infections, tumors). The time frame for autopsy and brain processing was less than $6 \mathrm{~h}$.

When comparing CHAT expression among brain regions, in both the frontal and entorhinal cortices it is higher than the parietal and temporal cortices in both groups. However, when comparing between groups, in all brain regions it is lower in the AD group than in the control group (Figure 2A). Despite these variations, in the control group the ChAT protein levels were constant, whereas in the AD group a peak in the entorhinal cortex and a remarkable decrease in the frontal region were found (Figure 2B, $p>0.05$, Wilcoxon test). In the AD group, ChAT protein expression in both the temporal and parietal regions was similar although slightly lower than in the control group (Figure 2B, $p>0.05$, Wilcoxon test). On the other hand, regional analysis of the NRSF gene showed an expression pattern similar to that of the CHAT gene (higher in the frontal and lower in the temporal cortices, $\mathrm{p}>0.05$; Wilcoxon test). Unlike the greater CHAT expression in the control group, the NRSF expression was greater in the AD group, while the NRSF protein expression was not constant (greater in the temporal region, with similar levels in the frontal, entorhinal and parietal regions; $p>0.05$, Wilcoxon test, see Figure 2C, D).

Average analysis of both ChAT and NRSF gene and protein expression showed the CHAT gene expression to be 39\% lower in the $\mathrm{AD}$ than in the control group $(\mathrm{p}<0.05$, $\mathrm{U}$ test), and its protein expression to be $17 \%$ lower in the $\mathrm{AD}$ than in the control group ( $\mathrm{p}=0.02$, $\mathrm{U}$ test). In contrast, the NRSF gene expression was increased by $86 \%$ in the AD group as compared to the control group $(\mathrm{p}=0.001$, $\mathrm{U}$ test $)$ 

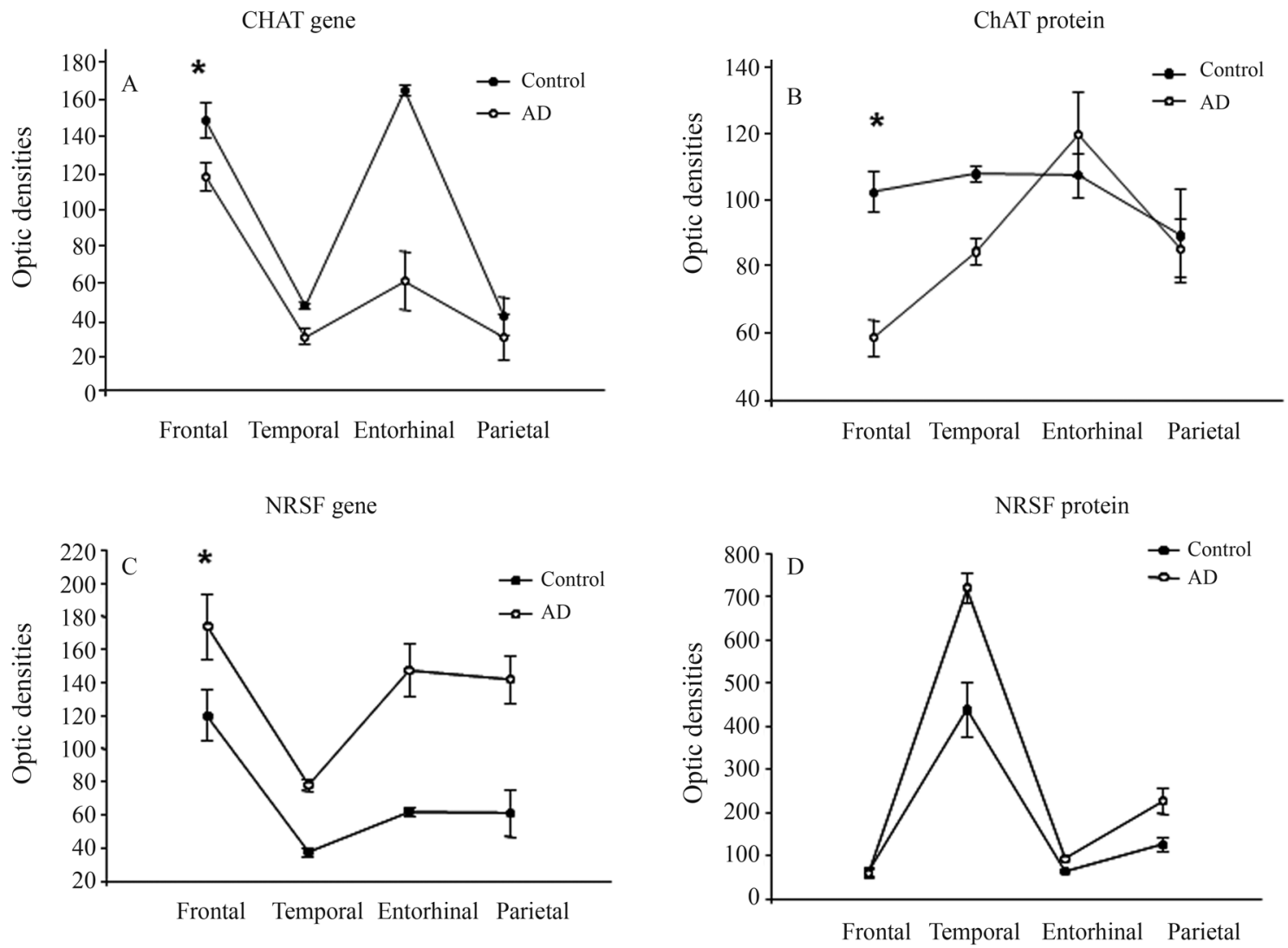

Figure 2 - CHAT and NRSF gene and protein expression. A. The CHAT expression curve in both groups is similar, although lower in the AD group. B. The ChAT curve is constant in the control group, whereas in the AD group it presents a peak in the entorhinal cortex and a decrease in the frontal region. C. The NRSF expression curve is similar in both groups, but higher in the AD group. D. The NRSF protein is higher in the AD group. Data are shown as mean \pm S.E., * statistically significant, $U$ test; $\mathrm{p} \leq 0.05$, Wilcoxon test.

\section{ChAT gene and protein expression}
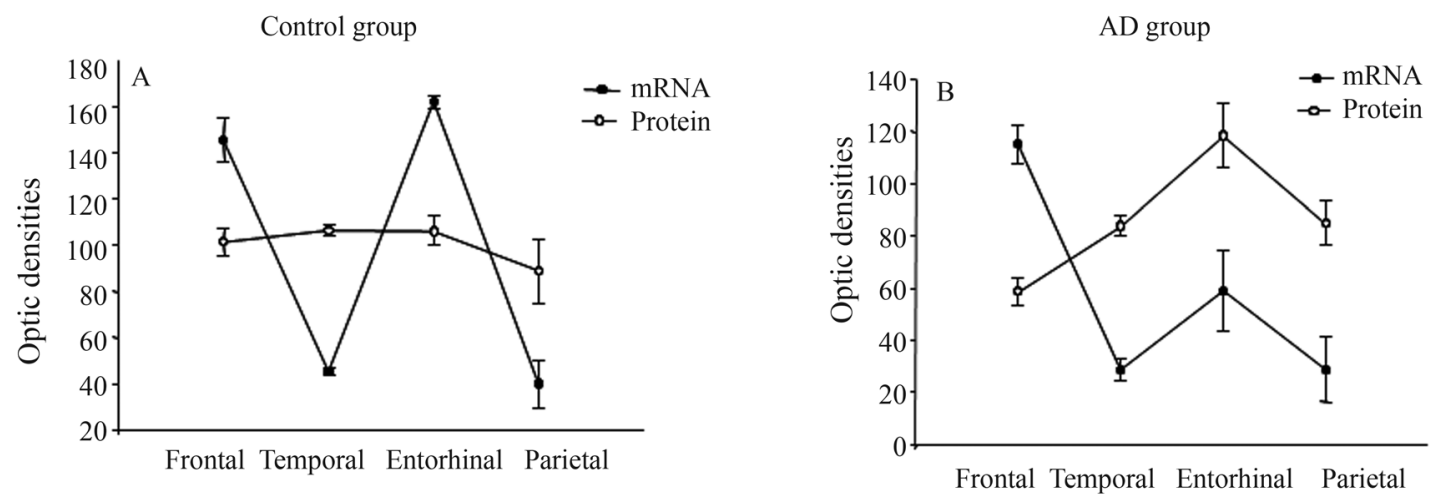

Figure 3 - CHAT gene and protein expression in the frontal, temporal, entorhinal and parietal regions of: A. the control group; B. the AD group. Data are shown as mean \pm S. E., $\mathrm{p} \leq 0.05$, Wilcoxon test.

and the expression of its protein increased by $57 \%$ ( $\mathrm{p}>0.05$, U test).

In addition to CHAT gene expression, we determined the ChAT protein concentrations, in order to evaluate the genetic information corresponding to the total amount of protein produced. As can be seen in Figure 3, in the AD group the ChAT protein concentrations varied in all the brain regions, being higher than the CHAT gene expression in the temporal, entorhinal and parietal cortices, albeit with the same distribution pattern. Thus, except for the frontal region, the ChAT protein expression was observed to correspond to the CHAT gene expression. In contrast, the opposite was found in the control group. 

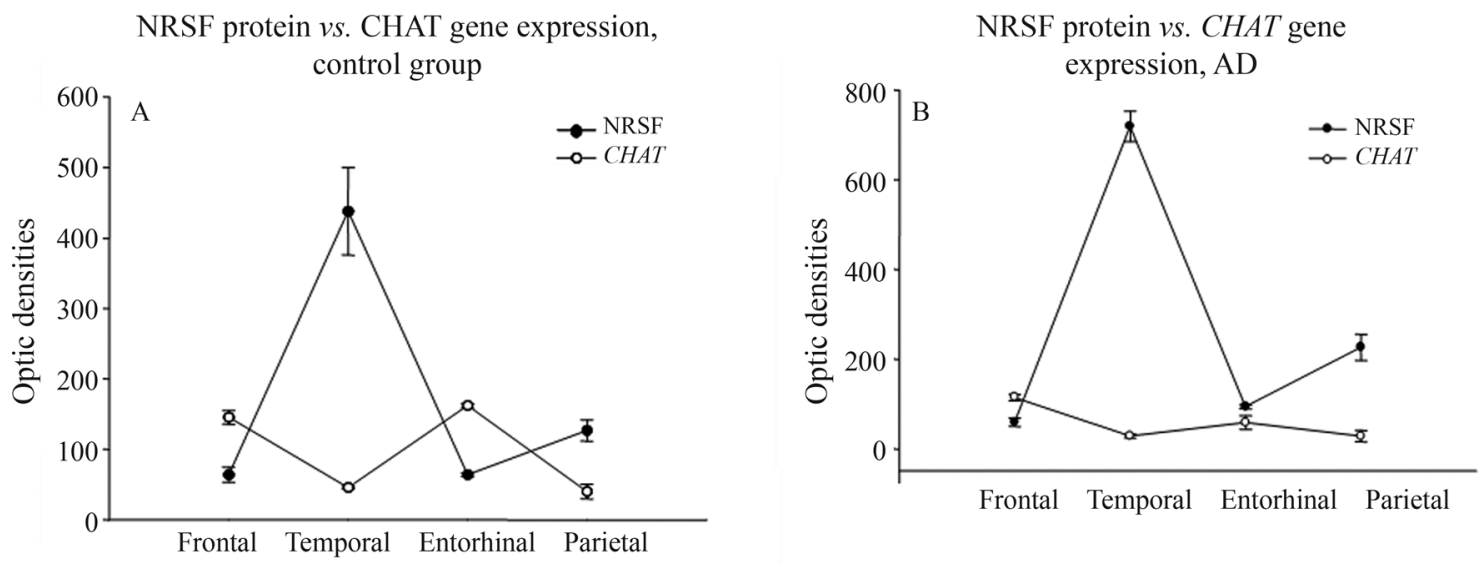

Figure 4 - CHAT gene expression and NRSF protein levels in the frontal, temporal, entorhinal and parietal regions of: A. the control group; B. the AD group. Data are shown as mean $\pm \mathrm{S}$. E., $\mathrm{p} \leq 0.05$, Wilcoxon test.

Comparing NRSF protein concentration and CHAT gene expression, an inverse relationship (high NRSF with low CHAT and vice versa) was observed in the control group, with lower CHAT levels in both the temporal and parietal cortices ( $p>0.05$; Wilcoxon test, Figure 4A). The same was found in the AD group ( $p>0.05$, Wilcoxon test, Figure 4B).

\section{Discussion}

In this pilot study, we found a decreased expression of both CHAT gene and protein levels, and an overexpression of the NRSF gene in AD patients as compared to the control group. This is the first study showing such a relationship in the human brain.

Increasing evidence indicates that the CHAT gene expression can be regulated by the NRSF protein (Shimojo et al., 1998; Hersh and Shimojo, 2003). NRSF is a transcription factor that regulates neuronal activity in the adult brain. This is consistent with a role for the NRSF-NRSE system in modulating gene expression rather than simply acting as an ON/OFF switch under different circumstances (Schoenherr and Anderson, 1995; Schoenherr et al., 1996).

In the present study, the increased NRSF levels and the decreased CHAT expression in the cerebral regions studied are in agreement with the behavior of this complex (i.e., the negative regulation of CHAT expression by the NRSF protein). This NRSF/CHAT interaction is similar to that observed in both the murine model and cell cultures (Chong et al., 1995; Chen et al., 1998; Jones and Meech, 1999; Hersh and Shimojo, 2003).

The higher expression of CHAT in the frontal region of the control group may be explained by the presence of cholinergic fibers coming from several areas, mainly from the Nucleus Basalis of Meynert (Selden et al., 1998). Considering the presence of motor, memory and behavior control circuits in the frontal cortex (Karczmar, 1990, 1993; Pepeu, 1993), we speculate that these are acetylcholinergic circuits and need ChAT to recycle choline in order to maintain the chemical signal to the circuit.

The findings in the entorhinal cortex may be attributed to the presence of numerous cholinergic afferents in this region, mainly coming from the Vertical Diagonal Band of Broca and the Basal Nucleus of Meynert (Mesulam, 1996; Mesulam and Geula, 1988; Semba et al., 1989). The proximity of the entorhinal cortex to the hippocampus, the amygdala and the cingulate gyrus is correlated with the cholinergic pathways (Squire and Zola-Morgan, 1991; Wible et al., 1992; Price, 2000).

We found that the NRSF expression in the control group was practically constant, but diminished in the temporal cortex. Furthermore, the NRSF protein expression was significantly increased in this region. This may be due to a post-transcriptional regulation of the NRSF expression (Lewin, 2000; Luque, 2002).

Neither the expression of CHAT nor its protein diminished in the same proportion to the increase of NRSF/NRSF suggesting that, at least in the temporal region, the protein NRSF regulates more than a single gene. This gene regulates the expression of other genes, such as BDNF (Timmusk et al., 1999), synapsine I (Thiel et al., 1994), SCG10 (Mori et al., 1992; Mori et al., 1990), $\mathrm{Na}+$ channel (Mori et al., 1992), nicotinic receptor (Bessis et al., 1995), muscarinic receptor, and others (Roopra et al., 2000). The role of NRSF protein in this region is probably not limited to the regulation of CHAT expression only, but also to some other genes as those described above. A co-regulation of CHAT by any of the above mentioned genes may also be involved.

We determined ChAT protein concentrations besides CHAT gene expression to evaluate the genetic information corresponding to the total amount of the produced protein. We found that (by exception of the frontal region in the AD group) ChAT protein expression was closely associated to CHAT gene expression, whereas in the control group an inverse relationship was found. The fact that ChAT protein 
A
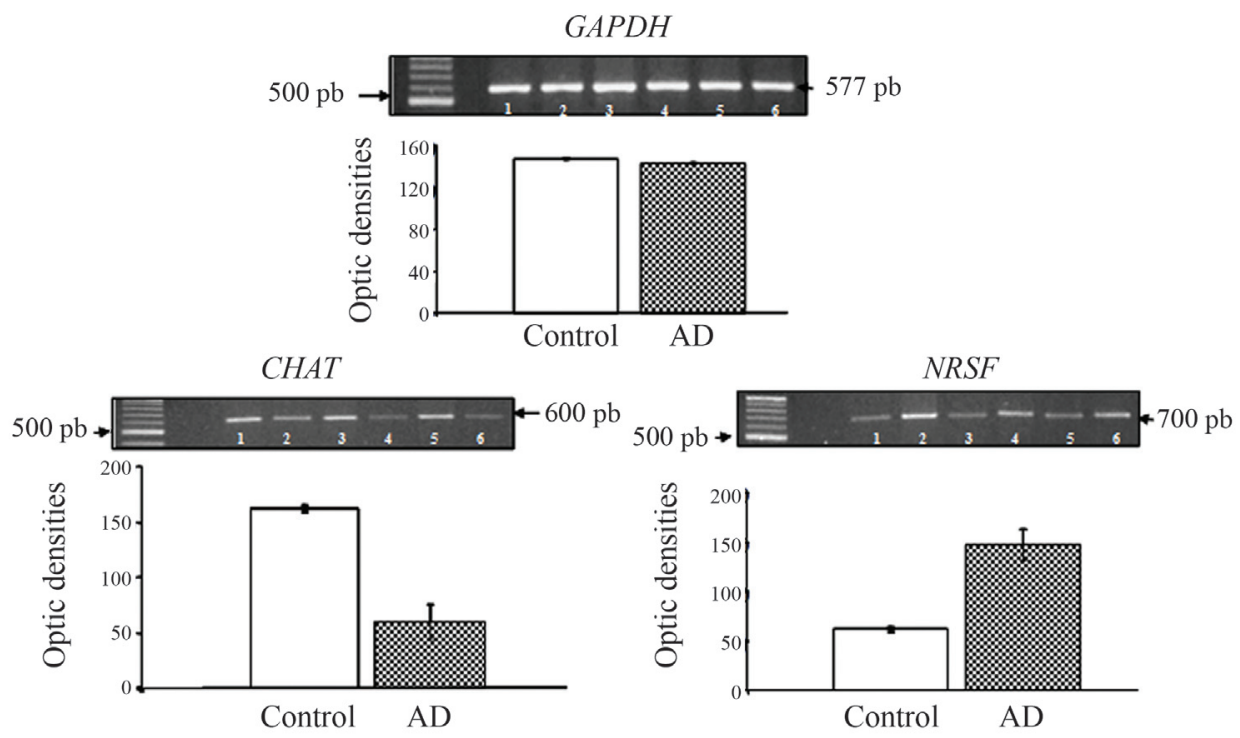

$\mathrm{B}$
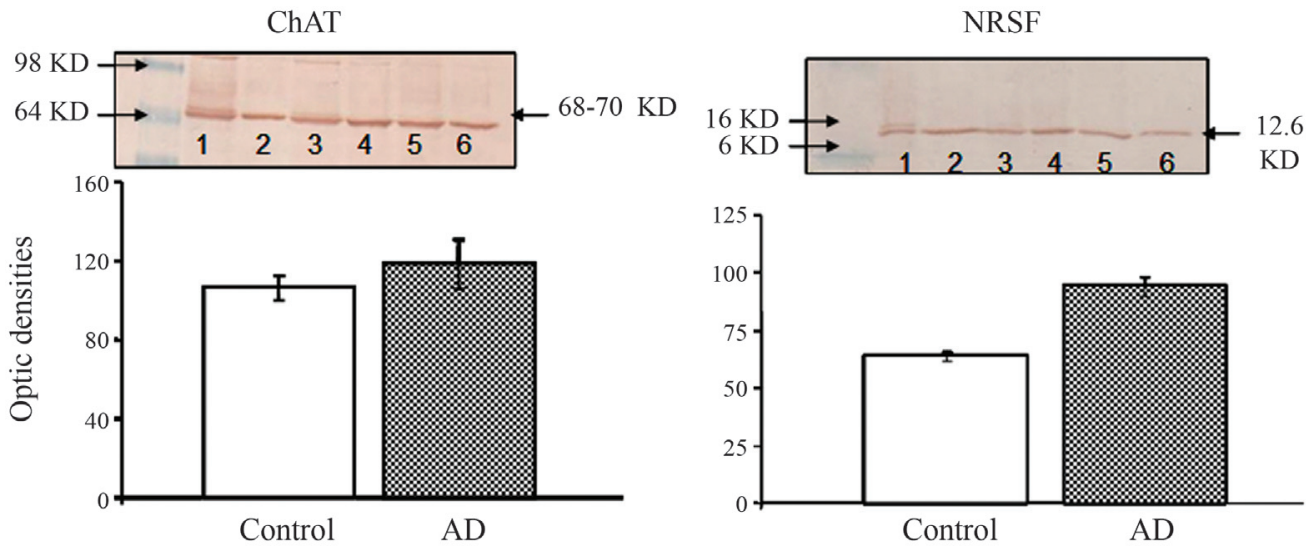

Figure 5 - A. Agarose gel electrophoresis of the RT-PCR products of GDPH, CHAT and NRSF. B. ChAT and NRSF protein detection by Western Blot in the entorhinal cortex of the $\mathrm{AD}$ and Control groups. Molecular weights are indicated in $\mathrm{kDa} .1,3$ and 5: control group; 2, 4 and 6: $\mathrm{AD}$ group. Graphs show the relative expression quantification in the entorhinal cortex of both the $\mathrm{AD}$ and control groups. Data are shown as mean $\pm \mathrm{S}$. E., $\mathrm{p}=0.05$, Wilcoxon test.

levels highly overpass the expression of CHAT in the parietal and temporal region may be explained by the numerous cholinergic afferents originated in the Ventral Tegmental Nucleus (for the temporal region) and the Medial Septal Nucleus (for the parietal region) (Fibiger, 1982; Gaykema et al., 1990; Mesulam, 1996). Consequently, ChAT may be produced in distant places and transported toward the synaptic button (Martinez-Murillo et al., 1989; Oda et al., 1992, 1996; Jones, 2004).

High CHAT expression associated with decreased ChAT levels may indicate that the frontal region receives afferents from distal connectivity and with probably little local circuitry (Oda et al., 1992, 1996). Production of the protein in the frontal and entorhinal cortex or from fibers coming directly from the Nucleus Basalis of Meynert probably contributes to the high values of ChAT enzyme in the parietal and temporal regions, maintaining circuits with these zones. To verify these circuits, subsequent studies are required in order to confirm the cerebral distribution sites of Ach and ChAT enzyme produced in the frontal and entorhinal regions.

ChAT expression in the AD group showed a similar tendency to that of the control group: higher in the frontal and entorhinal regions and lower in the parietal and temporal lobes, but in all of the cases CHAT expression was lower in the $\mathrm{AD}$ group. This is in line with previous reports describing a decrease in the cholinergic activity in different cerebral regions of patients with $\mathrm{AD}$ (Boissiere et al., 1997; Garcia-Alloza et al., 2005; Ikonomovic et al., 2005, 2011).

NRSF expression was higher in the AD group than in the control group: as compared to the control group, NRSF expression and NRSF production were increased in the AD group by $86 \%$ and $57 \%$, respectively. An increased NRSF protein production was also observed in the temporal region in both groups. In the AD subjects, this proportion was maintained although with higher expression, showing an 
important regulatory effect. These findings could be a consequence of neuronal damage (Palm et al., 1998; Timmusk et al., 1999). The temporal region is one of the most vulnerable to damage produced by the accumulation of the $\beta$-amyloid protein as well as of the tau protein (Pakaski and Kalman, 2008), which may increase NRSF expression. Since there was also a NRSF overexpression, a negative feedback may act at the nuclear level. In other words, there seems to be a mechanism of direct signposting between the damaged neuronal tissue and the gene expression. It would be necessary to study how this process participates in the neurodegeneration present in $\mathrm{AD}$ and whether this is a direct or a mediated effect.

The lower ChAT levels in the frontal lobe may be due to neurodegeneration of cholinergic afferents (Nunes-Tavares et al., 2012). Therefore, high ChAT expression may be due to the persistence of cholinergic afferents. Thus, the deafferentation seems to be presented in long axons cholinergic systems than in short axons.

In conclusion, our data suggest that NRSF is related to a decreased CHAT expression in human neural tissue. This CHAT expression has a topographical distribution, being more important in areas neurodegenerated by AD. The influence of the loss of cholinergic regulation on some of the symptoms of AD still needs to be assessed.

\section{Acknowledgments}

This work was supported by CONACyT; Fondo Sectorial en Salud 14195, and FIS: 2005/1/I/148; IMSS. México.

\section{References}

Abel C, Allegri RF, Garau L, Genovese O and Mangone CA (2008) Treatment of Alzheimer's Disease cognitive symptoms. Vertex 19(Suppl):39-47.

Auld DS, Kornecook TJ, Bastianetto S and Quirion R (2002) Alzheimer's disease and the basal forebrain cholinergic system: Relations to beta-amyloid peptides, cognition, and treatment strategies. Prog Neurobiol 68:209-245.

Belyaev ND, Wood IC, Bruce AW, Street M, Trinh JB and Buckley NJ (2004) Distinct RE-1 silencing transcription factor-containing complexes interact with different target genes. J Biol Chem 279:556-561.

Berrard S, Varoqui H, Cervini R, Israel M, Mallet J and Diebler MF (1995) Coregulation of two embedded gene products, choline acetyltransferase and the vesicular acetylcholine transporter. J Neurochem 65:939-942.

Berse B and Blusztajn JK (1995) Coordinated up-regulation of choline acetyltransferase and vesicular acetylcholine transporter gene expression by the retinoic acid receptor alpha, cAMP, and leukemia inhibitory factor/ciliary neurotrophic factor signaling pathways in a murine septal cell line. J Biol Chem 270:22101-22104.

Bessis A, Salmon AM, Zoli M, Le Novere N, Picciotto M and Changeux JP (1995) Promoter elements conferring neuron-specific expression of the beta 2-subunit of the neuronal nicotinic acetylcholine receptor studied in vitro and in transgenic mice. Neuroscience 69:807-819.

Boissiere F, Faucheux B, Agid Y and Hirsch EC (1997) Choline acetyltransferase mRNA expression in the striatal neurons of patients with Alzheimer's disease. Neurosci Lett 225:169-172.

Cerpa W, Dinamarca MC and Inestrosa NC (2008) Structurefunction implications in Alzheimer's disease: Effect of Abeta oligomers at central synapses. Curr Alzheimer Res 5:233-243.

Chen ZF, Paquette AJ and Anderson DJ (1998) NRSF/REST is required in vivo for repression of multiple neuronal target genes during embryogenesis. Nat Genet 20:136-142.

Chomczynski P and Sacchi N (1987) Single-step method of RNA isolation by acid guanidinium thiocyanate-phenol-chloroform extraction. Anal Biochem 162:156-159.

Chong JA, Tapia-Ramirez J, Kim S, Toledo-Aral JJ, Zheng Y, Boutros MC, Altshuller YM, Frohman MA, Kraner SD and Mandel G (1995) REST: A mammalian silencer protein that restricts sodium channel gene expression to neurons. Cell 80:949-957.

Coyle JT, Price DL and DeLong MR (1983) Alzheimer's disease: A disorder of cortical cholinergic innervation. Science 219:1184-1190.

De Gois S, Houhou L, Oda Y, Corbex M, Pajak F, Thevenot E, Vodjdani G, Mallet J and Berrard S (2000) Is RE1/NRSE a common cis-regulatory sequence for ChAT and VAChT genes? J Biol Chem 275:36683-36690.

DeKosky ST, Harbaugh RE, Schmitt FA, Bakay RA, Chui HC, Knopman DS, Reeder TM, Shetter AG, Senter HJ and Markesbery WR (1992) Cortical biopsy in Alzheimer's disease: Diagnostic accuracy and neurochemical, neuropathological, and cognitive correlations. Intraventricular Bethanecol Study Group. Ann Neurol 32:625-632.

Fibiger HC (1982) The organization and some projections of cholinergic neurons of the mammalian forebrain. Brain Res 257:327-388.

Garcia-Alloza M, Gil-Bea FJ, Diez-Ariza M, Chen CP, Francis PT, Lasheras B and Ramirez MJ (2005) Cholinergic-serotonergic imbalance contributes to cognitive and behavioral symptoms in Alzheimer's disease. Neuropsychologia 43:442-449.

Gaykema RP, Luiten PG, Nyakas C and Traber J (1990) Cortical projection patterns of the medial septum-diagonal band complex. J Comp Neurol 293:103-124.

Geula C, Nagykery N, Nicholas A and Wu CK (2008) Cholinergic neuronal and axonal abnormalities are present early in aging and in Alzheimer disease. J Neuropathol Exp Neurol 67:309-318

Hahm SH, Chen L, Patel C, Erickson J, Bonner TI, Weihe E, Schafer MK and Eiden LE (1997) Upstream sequencing and functional characterization of the human cholinergic gene locus. J Mol Neurosci 9:223-236.

Haroutunian V, Schnaider-Beeri M, Schmeidler J, Wysocki M, Purohit DP, Perl DP, Libow LS, Lesser GT, Maroukian M and Grossman HT (2008) Role of the neuropathology of Alzheimer disease in dementia in the oldest-old. Arch Neurol 65:1211-1217.

Heese K and Akatsu H (2006) Alzheimer's disease - An interactive perspective. Curr Alzheimer Res 3:109-121. 
Hersh LB and Shimojo M (2003) Regulation of cholinergic gene expression by the neuron restrictive silencer factor/repressor element-1 silencing transcription factor. Life Sci 72:20212028.

Ikonomovic MD, Mufson EJ, Wuu J, Bennett DA and DeKosky ST (2005) Reduction of choline acetyltransferase activity in primary visual cortex in mild to moderate Alzheimer's disease. Arch Neurol 62:425-430.

Ikonomovic MD, Klunk WE, Abrahamson EE, Wuu J, Mathis CA, Scheff SW, Mufson EJ and DeKosky ST (2011) Precuneus amyloid burden is associated with reduced cholinergic activity in Alzheimer disease. Neurology 77:39-47.

Jones BE (2004) Activity, modulation and role of basal forebrain cholinergic neurons innervating the cerebral cortex. Prog Brain Res 145:157-169.

Jones FS and Meech R (1999) Knockout of REST/NRSF shows that the protein is a potent repressor of neuronally expressed genes in non-neural tissues. Bioessays 21:372-376.

Kar S, Slowikowski SP, Westaway D and Mount HT (2004) Interactions between beta-amyloid and central cholinergic neurons: Implications for Alzheimer's disease. J Psychiatry Neurosci 29:427-441.

Karczmar AG (1990) Physiological cholinergic functions in the CNS. Prog Brain Res 84:437-466.

Karczmar AG (1993) Brief presentation of the story and present status of studies of the vertebrate cholinergic system. Neuropsychopharmacology 9:181-199.

Lehericy S, Hirsch EC, Cervera-Pierot P, Hersh LB, Bakchine S, Piette F, Duyckaerts C, Hauw JJ, Javoy-Agid F and Agid Y (1993) Heterogeneity and selectivity of the degeneration of cholinergic neurons in the basal forebrain of patients with Alzheimer's disease. J Comp Neurol 330:15-31.

Lewin B (2000) Transcription. In: Lewin B (ed) Genes VII. Oxford University Press and Cell Press, New York, pp 233271.

Lonnerberg P, Schoenherr CJ, Anderson DJ and Ibanez CF (1996) Cell type-specific regulation of choline acetyltransferase gene expression. Role of the neuron-restrictive silencer element and cholinergic-specific enhancer sequences. J Biol Chem 271:33358-33365.

Lowry OH, Rosebrough NJ, Farr AL and Randall RJ (1951) Protein measurement with the Folin phenol reagent. J Biol Chem 193:265-275.

Luque JH and Hernández A (2002) Maduración del RNA o procesamiento postranscripcional. In: Biología Molecular e Ingeniería Genética. Harcourt/Gráficas Marte S.A, Madrid, pp 275-284.

Maccioni RB, Otth C, Concha II and Munoz JP (2001) The protein kinase Cdk5. Structural aspects, roles in neurogenesis and involvement in Alzheimer's pathology. Eur J Biochem 268:1518-1527.

Martin JB (1999) Molecular basis of the neurodegenerative disorders. N Engl J Med 340:1970-1980.

Martinez-Murillo R, Villalba R, Montero-Caballero MI and Rodrigo J (1989) Cholinergic somata and terminals in the rat substantia nigra: An immunocytochemical study with optical and electron microscopic techniques. J Comp Neurol 281:397-415.

Mesulam MM (1996) The systems-level organization of cholinergic innervation in the human cerebral cortex and its alterations in Alzheimer's disease. Prog Brain Res 109:285-297.
Mesulam MM and Geula C (1988) Nucleus basalis (Ch4) and cortical cholinergic innervation in the human brain: Observations based on the distribution of acetylcholinesterase and choline acetyltransferase. J Comp Neurol 275:216-240.

Mieda M, Haga T and Saffen DW (1997) Expression of the rat $m 4$ muscarinic acetylcholine receptor gene is regulated by the neuron-restrictive silencer element/repressor element 1 . J Biol Chem 272:5854-5860.

Mori N, Stein R, Sigmund O and Anderson DJ (1990) A cell type-preferred silencer element that controls the neuralspecific expression of the SCG10 gene. Neuron 4:583-594.

Mori N, Schoenherr C, Vandenbergh DJ and Anderson DJ (1992) A common silencer element in the SCG10 and type II Na+ channel genes binds a factor present in nonneuronal cells but not in neuronal cells. Neuron 9:45-54.

Mufson EJ, Ginsberg SD, Ikonomovic MD and DeKosky ST (2003) Human cholinergic basal forebrain: Chemoanatomy and neurologic dysfunction. J Chem Neuroanat 26:233-242.

Nunes-Tavares N, Santos LE, Stutz B, Brito-Moreira J, Kein WL, Ferreira ST and de Mello FG (2012) Inhibition of choline acetyltransferase as a mechanism for cholinergic dysfunction induced by amyloid- $\beta$ peptide oligomers. J Biol Chem 287:19377-19385.

Oda Y, Nakanishi I and Deguchi T (1992) A complementary DNA for human choline acetyltransferase induces two forms of enzyme with different molecular weights in cultured cells. Brain Res Mol Brain Res 16:287-294.

Oda Y, Muroishi Y and Nakanishi I (1996) Translation initiation sites and relative activity of large and small forms of human choline acetyltransferase. Brain Res Mol Brain Res 38:135138.

Oda Y, Muroishi Y, Misawa H and Suzuki S (2004) Comparative study of gene expression of cholinergic system-related molecules in the human spinal cord and term placenta. Neuroscience 128:39-49.

Pakaski M and Kalman J (2008) Interactions between the amyloid and cholinergic mechanisms in Alzheimer's disease. Neurochem Int 53:103-111.

Palm K, Belluardo N, Metsis M and Timmusk T (1998) Neuronal expression of zinc finger transcription factor REST/NRSF/XBR gene. J Neurosci 18:1280-1296.

Palm K, Metsis M and Timmusk T (1999) Neuron-specific splicing of zinc finger transcription factor REST/NRSF/XBR is frequent in neuroblastomas and conserved in human, mouse and rat. Brain Res Mol Brain Res 72:30-39.

Pepeu G (1993) Overview and future directions of CNS cholinergic mechanisms. Prog Brain Res 98:455-458.

Price DL (2000) Aging of the brain and dementia of the Alzheimer type. In: Kandel ER and Jessel TM (ed) Principles of Neural Sciences. McGraw-Hill, New York, pp 1149-1168.

Roopra A, Sharling L, Wood IC, Briggs T, Bachfischer U, Paquette AJ and Buckley NJ (2000) Transcriptional repression by neuron-restrictive silencer factor is mediated via the Sin3histone deacetylase complex. Mol Cell Biol 20:2147-2157.

Schoenherr CJ and Anderson DJ (1995) The neuron-restrictive silencer factor (NRSF): A coordinate repressor of multiple neuron-specific genes. Science 267:1360-1363.

Schoenherr CJ, Paquette AJ and Anderson DJ (1996) Identification of potential target genes for the neuron-restrictive silencer factor. Proc Natl Acad Sci USA 93:9881-9886. 
Selden NR, Gitelman DR, Salamon-Murayama N, Parrish TB and Mesulam MM (1998) Trajectories of cholinergic pathways within the cerebral hemispheres of the human brain. Brain 121:2249-2257.

Semba K, Reiner PB, McGeer EG and Fibiger HC (1989) Brainstem projecting neurons in the rat basal forebrain: Neurochemical, topographical, and physiological distinctions from cortically projecting cholinergic neurons. Brain Res Bull 22:501-509.

Shimojo M, Paquette AJ, Anderson DJ and Hersh LB (1999) Protein kinase A regulates cholinergic gene expression in $\mathrm{PC} 12$ cells: REST4 silences the silencing activity of neuronrestrictive silencer factor/REST. Mol Cell Biol 19:67886795.

Shimojo M, Wu D and Hersh LB (1998) The cholinergic gene locus is coordinately regulated by protein kinase A II in PC12 cells. J Neurochem 71:1118-1126.

Squire LR and Zola-Morgan S (1991) The medial temporal lobe memory system. Science 253:1380-1386.

Tanaka H, Zhao Y, Wu D and Hersh LB (1998) The use of DNase I hypersensitivity site mapping to identify regulatory regions of the human cholinergic gene locus. J Neurochem 70:1799-1808.

Thiel G, Schoch S and Petersohn D (1994) Regulation of synapsin I gene expression by the zinc finger transcription factor zif268/egr-1. J Biol Chem 269:15294-15301.

Timmusk T, Palm K, Lendahl U and Metsis M (1999) Brainderived neurotrophic factor expression in vivo is under the control of neuron-restrictive silencer element. J Biol Chem 274:1078-1084.

Watson D, Castaño E, Kokjohn TA, Kuo YM, Lyubchenko Y, Pinsky D, Connolly Jr ES, Esh C, Luehrs DC, Stine WB, et al. (2005). Physicochemical characteristics of soluble oligomeric Abeta and their pathologic role in Alzheimer's disease. Neurol Res 27:869-881.

Wible CG, Shiber JR and Olton DS (1992) Hippocampus, fimbria-fornix, amygdala, and memory: Object discriminations in rats. Behav Neurosci 106:751-761.

Wilcock GK, Esiri MM, Bowen DM and Smith CC (1982) Alzheimer's disease. Correlation of cortical choline acetyltransferase activity with the severity of dementia and histological abnormalities. J Neurol Sci 57:407-417.

Wood IC, Belyaev ND, Bruce AW, Jones C, Mistry M, Roopra A and Buckley NJ (2003) Interaction of the repressor element 1-silencing transcription factor (REST) with target genes. J Mol Biol 334:863-874.

World Medical Association (2008) Declaration of Helsinki: Ethical Principles for Medical Research Involving Human Subjects. In: W.M. Association, ed. 59th General Assembly, Seoul.

Yan Z and Feng J (2004) Alzheimer's disease: Interactions between cholinergic functions and beta-amyloid. Curr Alzheimer Res 1:241-248.

Associate Editor: Maria Rita Passos Bueno

License information: This is an open-access article distributed under the terms of the Creative Commons Attribution License, which permits unrestricted use, distribution, and reproduction in any medium, provided the original work is properly cited. 